Fall 10-1-2007

\title{
The Clergy of Early Seventeenth-Century France: Self-Perception and Society's Perception
}

\author{
J. M. Hayden \\ Malcolm R. Greenshields
}

Follow this and additional works at: https://via.library.depaul.edu/vhj

\section{Recommended Citation}

Hayden, J. M. and Greenshields, Malcolm R. (2007) "The Clergy of Early Seventeenth-Century France: SelfPerception and Society's Perception," Vincentian Heritage Journal: Vol. 27: Iss. 1, Article 8.

Available at: https://via.library.depaul.edu/vhj/vol27/iss1/8 


\title{
The Clergy of Early Seventeenth-Century France: Self-Perception and Society's Perception ${ }^{1}$
}

\author{
BY \\ J. Michael Hayden AND \\ Malcolm R. GREenSHIELDS
}

The Catholic Reformation in France has been the subject of many studies during the past twenty years. ${ }^{2}$ It is becoming increasingly apparent that agreement is lacking on when this Reformation began and what the state of the French church actually was during that time. ${ }^{3}$ Because almost everyone in early modern France lived in rural areas, these questions cannot be answered without a thorough understanding of the rural clergy and their parishioners. Recently the publication of a repertoire of pastoral visits has opened up the possibility of studying the parish clergy of France. ${ }^{4}$ To date, several

1 Originally published in French Historical Studies, Volume 18:1, pp. 145-172. Copyright, 1993, the Society of French Historical Studies. All rights reserved. Used by permission of the publisher, Duke University Press.

2 The works of Jean Delumeau have been influential, especially Le Catholicisme entre Luther et Voltaire (Paris, 1971, 2nd ed., 1978). Among other important books, in addition to those listed in footnotes 2 and 4, are A.N. Galpern, The Religions of the People in Sixteenth-Century Champagne (Cambridge, Mass., 1976); Peter Burke, Popular Culture in Early Modern Europe (New York, 1978); Robert Muchembled, Culture populaire et culture des élites dans la France moderne (Paris, 1978); John Bossy, Christianity in the West, 14001700 (Oxford, 1985); Louis Chitellier, The Europe of the Devout: The Catholic Reformation and the Formation of a New Society, Jean Birrell, trans. (Cambridge, 1989); Robin Briggs, Communities of Belief (Oxford, 1989).

3 Compare statements in Louis Welter, La Réforme ecclésiastique du diocèse Clermont au XVIle siècle (Paris, 1956), 19-21; Jeanne Ferté, La Vie religieuse dans les campagnes parisiennes, 1622-1695 (Paris, 1962), 184; Louis Pérouas, Le Diocèse de La Rochelle de 1648 à 1724 (Paris, 1964), 194-205; Robert Sauzet, Les Visites pastorales dans le diocèse de Chartres pendant la première moitié du XVIle siècle (Rome, 975), 115-92; Sauziet, Contre-Réforme et réforme catholique en Bas-Languedoc: Le Diocèse de Nîmes au XVIle siècle (Louvain, 1979), 79141, 325-76, 500-01; René Tavenaux, Le Catholicisme dans la France classique (Paris, 1980), 1:137-44; Philip Hoffman, Church and Community in the Diocese of Lyon (New Haven, 1984), 3, 5, 44-52, 71-83, 98-101; Marie-Hélène and Michel Froeschlé-Chopard, Atlas de la réforme pastorale en France (Paris, 1986), 29-32.

4 Centre National de la Recherche Scientifique, Répertoire des visites pastorales de la France. Première serie. Anciens diocèses (jusqu'en 1790), 4 vols. (Paris, 1977-85). For an idea of the scope of possibilities for research in pastoral visit records, see FroeschléChopard, Atlas. For the study of pastoral visits in Italy and Germany, see Umberto Mazzone and Angelo Turchini, eds., Le visite pastorali (Bologna, 1985). 
books have been published that make use of pastoral visits for one diocese. In addition, a number of articles and, perhaps, a dozen unpublished theses are available, mostly for the late seventeenth or eighteenth century. Most historians, however, have concentrated on general themes or highly placed individuals rather than on the ordinary clergy and local variations. ${ }^{5}$ Accounts of pastoral visits, along with benefice records, fabric registers, and synodal and ecclesiastical conference records and statutes, are being used by the Pastoral Visit Project to discover the resulting changes in the lives of the rural clergy and their parishioners in northwestern France. ${ }^{6}$

To understand the effects of change on lives, one needs to know both the original state of those lives and the contemporary perceptions of them. It is difficult, however, to find sufficient reliable information on how the clergy saw themselves and how others saw them in the late sixteenth and early seventeenth centuries. A partial solution to this problem is provided by the cahiers de doléances of the Estates General of 1614.

Interpretation of these documents is aided with an insight made by the German theologian, Paul Tillich. Some thirty years ago he identified an aspect of European thought that began, he said, with Thomas Aquinas and became more prevalent from the sixteenth century onward. He believed that, partly because of the program of Protestant and Catholic Reformers, religion was in the process of being relegated to a single isolated sphere of human thought and activity, whereas it had previously been regarded as an integral part of human nature and all human activity. ${ }^{7}$

\footnotetext{
Among the exceptions are Welter, Clermont; Ferté, La Vie religieuse; Pérouas, La Rochelle; Louis Châtellier, Tradition chrétienne et renouveau catholique dans l'ancien diocèse de Strasbourg (1650-1770) (Paris, 1981); Claire Dolan, Entre tours et clochers: Les Gens d'église à Aix-en-Provence au XVle siècle (Sherbrooke, 1981); A. Lottin, Lille: Citadelle de la Contre-Réforme (1598-1668)? (Dunkerque, 1984).

6 The project, supported by the Social Sciences and Humanities Research Council of Canada, is a study of the adaptation of the parish priests of northwestern France to Catholic Reform in the years spanning 1560-1720, and the effect this adaptation had on them and their parishioners. See Malcolm Greenshields, "An Introduction to the Pastoral Visit Project: Between Two Worlds, 1560-1720," Proceedings of the Annual Meeting of the Western Society for French History 15 (1988): 51-60; J. Michael Hayden, "The Pastoral Visit Project Phase I; The Dioceses of Coutances and Avranches," ibid., 61-70. 7 Theology of Culture (Oxford, 1959), 3-19. For the non-European context see 204-5. Roland Schulz brought this book to our attention.
} 


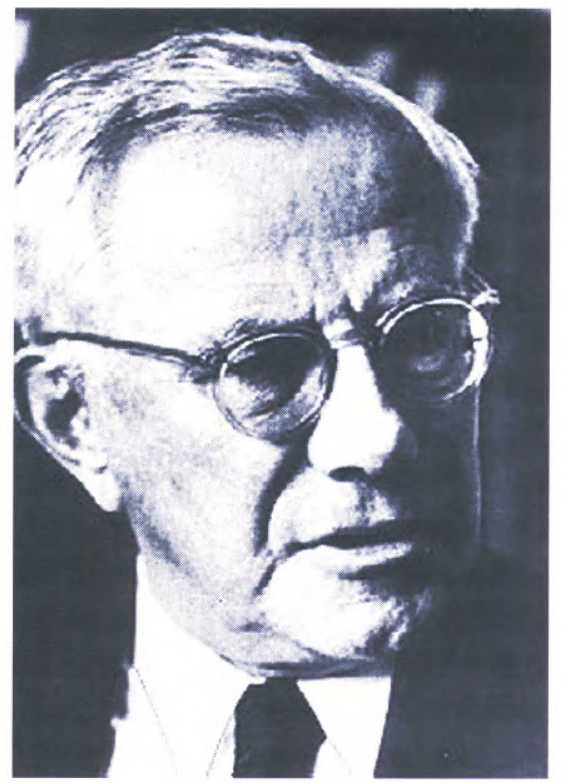

Paul Tillich (1886-1965).

Public Domain

In this article we will argue that the cahiers of 1614 are a useful source of information about public opinion. Using Tillich's insight, along with other available information, the cahiers will be analyzed to determine first, how the elite French clergy of the early seventeenth century viewed (a) themselves and the other members of the First Estate, (b) the role of that estate in society, and (c) its need for reform; and second, how this clerical self-perception compared with the views of a fairly wide cross-section of the Second and Third Estates.

\section{Cahiers as a Source of Public Opinion}

In his speech at the opening of the Estates General of 1614, Denis de Marquemont, archbishop of Lyon, though a leading reformer, presented a glowing picture of the clergy:

Dispensers of His sacraments and of His mysteries, shepherds of the sheepfold of God, interpreters of His oracles; we have the tables of the law to teach the 
people fear of God and obedience to the King, the rod to lead them, the manna to feed them. ${ }^{8}$

Clerics who were willing to publicly criticize other clerics were also to be found at the meeting. The boldest was Jean-Pierre Camus, bishop of Belley. Known for his ability as a preacher, he was asked to give a sermon at three of the seventeen weekly masses held for deputies, despite the fact that he strongly criticized all three estates. In one of his sermons he asked:

Where is the piety, where the devotion, where the conscience, where the honor, where the mark of our priesthood, where the holy love that we owe our Spouse? If we reject the crown of thorns, we will never have that of glory in happy eternity, where none will be crowned who have not fought here. ${ }^{9}$

The juxtaposition of these two quotations raises questions. Was Marquemont expressing an ideal, whereas Camus was complaining about reality? Which perception of the state of clerical life was closer to that of their contemporaries?

The traditional sources of opinion about clerics do not provide an answer to these questions. Clerics who wrote books about clerics were usually not in touch with the actual lives of the majority of their brethren. Pamphlets are not of much help either, because the clergy, though from time to time they might have carried on a quarrel over a particular privilege or post, did not use pamphlets to describe themselves to fellow clerics or to others. ${ }^{10}$ Pronouncements concerning the lack of education and the moral failings of the parish clergy were made by missionaries and reformers. But how accurate a portrait of either the clergy or the clergy's self-perception do these statements

8 Denis Simon de Marquemont, Harangue prononcée... à l'ouverture des Estats.... (Paris, 1615).

9 Jean-Pierre Camus, Homélies des Etats Généraux (1614-1615), Jean Descrains, ed. (Geneva, 1970), 313. Camus' most striking metaphor was applied to financiers who bought government offices. He described them as "ants of the Troglodytes, as big as wolves.... who eat only gold." Ibid., 237.

${ }^{10}$ J. Michael Hayden, "The Uses of Political Pamphlets: The Example of 1614-15 in France," Canadian Journal of History 21 (1986): 143-66. 
provide? ${ }^{11}$ One can pick individual scandals out of the registers of the deliberations of cathedral chapters, from the reports of pastoral visits, or from generalized statements from synodal statutes, but no quantitative studies yet exist. There is also the historical tradition - that the parish clergy of early seventeenth-century France were in great need of reform. ${ }^{12}$ But what was the reality?

Although doubts have been expressed about the possibility of using cahiers as sources for understanding public opinion, the local and national cahiers de doléances, prepared by all three estates for the Estates General of 1614, are excellent sources for answering the above questions. The proof of their excellence is that they have been used effectively by a number of historians to determine "public opinion."13 There are limitations created by the fact that cahiers were meant to emphasize grievances, not to make positive statements, and that only a minority of the population was involved in the process of cahier writing. ${ }^{14}$ The number of cahiers that are available also presents a problem. Whereas many cahiers prepared for the Estates General of 1789 are available, few of the 1614 cahiers still exist. ${ }^{15}$

${ }^{11}$ For a seventeenth-century missionary's list of the sins of clerics, see Jean Eudes, $L a$ Vie du chrétien ou le catéchisme de la mission in Oeuvres complètes du vénérable Jean Eudes, 12 vols. (Paris, 1906), 2:497-501. For an expression of his view of the exalted status of the priest, see Le Bon Confesseur in ibid., 4:151-62.

12 Compare, for example, John Bossy, Christianity in the West, 1400-1700 (Oxford, 1985), 65-66; James Brundage, Law, Sex, and Christian Society in Medieval Europe (Chicago, 1987), 214-22, 251-53, 314-19, 342-43, 405-5, 542-45, 567-69; Pérouas, La Rochelle, 200-201; Sauzet, Chartres, 108-9, 137-41, 147-49. The Pastoral Visit Project hopes to produce a quantitative study for northwestern France.

13 Yves Durand, ed., Cahiers de doléances de paroisses du bailliage de Troyes pour les états généraux de 1614 (Paris, 1966), 1-73; R. Chartier and J. Nagle, "Les Cahiers de doléances de 1614: Un Echantillon: Chatellenies et paroisses du bailliage de Troyes," Annales, E.S.C. 28 (1973): 1484-94; J. Michael Hayden, France and the Estates General of 1614 (Paris, 1974), 174-218; Malcolm Greenshields "The Relations of Sentiment between the Peasants and the Rural Nobility in the Cahiers to the French Estates General of 1614 " (M.A. thesis, University of Saskatchewan, 1978); R. Chartier and D. Richet, eds., Représentation E vouloir politique autour des états généraux de 1614 (Paris, 1982).

${ }^{14}$ For a detailed discussion of how the cahiers were drawn up, and by whom, in 1614, see Roger Chartiet, "La Convocation aux Etats de 1614: Note sur les formes politiques," in Chartier and Richet, Répresentation, 53-61; and Hayden, Estates General, 74-97.

${ }^{15}$ For a list of surviving cahiers for 1614, see Hayden, Estates General, 199, 201, 204-5. All potentially relevant archives and libraries were systematically searched. No other cahiers have been found in the intervening twenty years. Because of a modified classification scheme the numbers used below are slightly different than those in the lists cited above. 
In this article all the extant relevant material has been used: 201 cahiers (varying in size from the one short paragraph of the inhabitants of La Celle-Saint-Cyr in Champagne to the 609 [often long] paragraphs of the general cahier of the Third Estate), 20 fragments of cahiers, and 163 individual requests. These documents will be used in the context created by time, place, and the people involved.

At the local level, of the unknown number of cahiers that once existed for the Third Estate there remains those of the inhabitants of sixty-nine communities in the bailliage of Troyes, thirteen villages in Basse Auvergne, thirteen other cahiers, and twelve parts of cahiers from localities in five of the twelve governments of France, along with the grievances of 46 Parisian guilds, five from Troyes, and 163 requests by Parisian individuals. Three local cahiers remain for the clergy and none for the nobility. One can, therefore, provide detail about a few localities, but comparative studies would make no sense.

Of the 290 to 316 cahiers supposedly brought to the Estates General from the bailliages, sénéchaussées and other electoral districts of France, only 30 and the fragments of seven others remain. There is no geographic pattern of survival that would allow for meaningful quantitative analysis of patterns of response to various problems.

At the Estates General the deputies in ten governments in each estate drew up a cahier that was supposed to summarize those they had brought with them. Two of these remain for the First Estate, five, and the notes for a sixth, for the Third Estate, along with all ten for the nobility. The deputies of Brittany and Dauphiné prepared one cahier for all three estates; both exist. Thus, for the nobility, some comparison of response is possible. Finally, each estate drew up a general cahier to be presented to the king. All three are extant.

Again, unlike 1789, little is known about the individuals who drew up the preparatory cahiers. More is known about some of the deputies who actually participated in the Estates General itself, but for most participants at all levels only their qualité is known. ${ }^{16}$ Nevertheless, it can be stated with confidence that, at all levels, attitudes about the clergy were not significantly affected by the issues that led to the calling of the Estates General. Nor could those preparing the preliminary cahiers have gained any political or other

${ }^{16}$ For the deputies, see footnote 13 and Hayden, Estates General, 234-83. In addition to the very few local studies cited in those pages, see Chartier and Richet, Répresentation, 65-147. 
advantage by presenting any view of the clergy other than their own. ${ }^{17}$ Thus, there is every reason to believe that those who compiled the local and bailliage cahiers expressed their own ideas about the clergy. On the other hand, the governmental and general cahiers prepared during the meeting by each estate must be read in light of the fact that clerical claims of political authority engaged the interest of the deputies of the Second and Third Estates during the meetings. This may have influenced the insistence of lay deputies that clerical power be limited. ${ }^{18}$

The general cahiers of the First Estate best reflect the concerns of the elite-bishops, chapter members and in commendam abbots and priors - because these formed the largest groups in the meetings of 1614. The fifty-nine bishops present, with 70 of the 142 votes, were the most influential. In commendam abbots had 49 votes, while chapter members had 43. Members of religious orders had sixteen, curés thirteen, and diocesan officials had twelve votes. ${ }^{19}$ Of the thirteen curés present at the Paris meeting, only seven did not hold a diocesan or chapter office. Of these seven, four held doctorates in theology, and one was a seigneur. Thus, at most, only two ordinary rural curés (one from Burgundy, one from Orléans) were deputies. There is no evidence of the concerns of the rural clergy in the cahiers. In the twelve instances where bailliage or local cahiers were preserved for the First Estate the city clergy dominated. In some areas it was the bishop who was in control, in others it was the canons. The differences in the cahiers that resulted will be noted below.

In contrast, the noble deputies to the Estates General were quite representative of the Second Estate as a whole, with a predominance of chevaliers-seigneurs who could trace their ancestry to the fourteenth century or earlier - that is, members of the older lower nobility. In the eight instances where bailliage cahiers exist, the breakdown is the same.

\footnotetext{
${ }^{17}$ For issues and context, see Hayden, Estates General, 54-73.

18 The question of the protection of the king's life, in particular, had an influence. The debate over acceptance of the decrees of the Council of Trent did not. See ibid., 98-173.

${ }_{19}$ Deputies often possessed two qualités simultaneously. Also, some deputies represented more than one jurisdiction. Therefore the number of votes does not add up to 142 . For a more complete analysis see ibid., 89, and J. Michael Hayden, "Social Origins of the French Episcopacy at the Beginning of the Seventeenth Century," French Historical Studies 10 (1977): 27-40.
} 
The deputies of the Third Estate who came to Paris were not "typical" parishioners. Office holders dominated, with only nineteen of the 198 Third Estate deputies holding no administrative, judicial, or financial office. Only one deputy (Constantin Housset, listed as a resident of Flamanville in the bailliage of Caux in Normandy) might have been a peasant. Most probably he was a substantial farmer. At the local level distillation or screening out of some, but not all, peasant grievances is evident. The local Third Estate cahiers were usually the expression of an "élite villageoise." 20

\section{Clerical Self-Perception}

From the general cahier of the First Estate one can by inference develop a description of the deputies' concept of what clerics should be. ${ }^{21}$ In the minds of the city clergy who dominated the meetings they were to be "bons et capables Pasteurs \& Prelats" and/or benefice holders who were "personnes capables \& de bonne vie." "Bonne vie" was much less clearly defined in the general cahier than it was in the local ones and in the decrees of the Council of Trent, both of which mentioned specific abuses. "Capable" meant possessing the ability to discharge the functions attached to a benefice.

Those who wished to enter sacred orders (deacon, priest, bishop) were to have a benefice or a patrimony providing at least sixty livres rent a year, be of the proper age (twenty-two for the diaconate, twenty-four for the priesthood), and know Latin. Priests were to have attended a seminary (even though very few actually existed in France in 1614).

Clerics should have received their benefices in the proper manner from the proper authority, without simony and without giving all or some of the attached revenue to another, especially a lay person (a practice known as confidence). Holders of benefices with pastoral responsibilities attached were to be resident so that they could carry out their duties or, if officially excused for a valid reason, should

${ }^{20}$ Chartier and Nagle, "Les Cahiers de doléances de 1614," 1486-87. In some villages this elite comprised from a fifth to a third of the inhabitants. Rural workers, and most dependent peasants, were excluded.

${ }^{21}$ Cahier des remonstrances du clergé de France presenté au Roy durant les Estats Generaux du Royaume, tenus à Paris és annees mil six cens quatorze, E mil six cents quinze (Paris, 1615), 3-31, 61-66. 
provide a vicar with the proper training and qualities. All clerics were required to attend diocesan synods.

Curés were to be "gens de bien \& sans scandale" who were well instructed in the administration of the sacraments. They should know the dialect of the area they served. They should be careful to maintain their rights and privileges and ensure that those entrusted with the obligation provided for the upkeep of church buildings. Finally, they were to pay particular attention to teaching the catechism.

Cathedral and collegial canons should be of the proper age, in residence, and participants in all services in their church. Commendatory abbots, priors and anyone with a benefice should wear the tonsure and suitable clerical clothing and receive sacred orders upon attaining the age of twenty-two. Bishops were to found and maintain seminaries and carry out visitations of all the parishes under their jurisdiction to ensure that reform was instituted and maintained.

In both the decrees of Trent and the general cahier of the First Estate in 1614, members of religious orders were discussed separately and in less detail. The deputies titled the section that dealt with the secular or diocesan clergy "Concerning religion and the ecclesiastical state." A separate and much shorter chapter dealt with "regulars and monasteries." The implication was that only clerics, not unordained members of religious orders, made up the ecclesiastical state.

This distinction became typical of the late Catholic Reformation. ${ }^{22}$ It was expressed so clearly in the general cahier of 1614 because only eleven percent of the deputies of the First Estate were members of religious orders. Most, if not all, of these men were also ordained clerics. The deputies of the Second and Third Estates, however, continued to follow the older tradition. They treated clerics and religious together as members of both the First Estate and the ecclesiastical state.

Because the general cahier was a request by the clergy that the king help ensure that the ideal be attained, the implication, of ten made explicit in the wording, was that much work needed to be done before the ideal could exist. In the minds of deputies of the First Estate in 1614 , French clergy and religious needed significant reform. In other

${ }^{22}$ Joseph Bergin, "Between Estate and Profession: The Catholic Parish Clergy of Early Modern Western Europe," in Social Orders and Social Classes in Europe since 1500, ed. M.L. Bush (London, 1992), 66-85. 
words, the deputies' opinion of their fellow clerics - especially those not members of the elite groups present - was low. It was so low that article 37 of the general cahier asked that ecclesiastical courts be allowed to sentence clerics to the galleys for very serious crimes. The reasons for the request were that "censures, fasts and prisons" were not enough to restrain "Ecclesiastiques coupables \& incorrigibles" and that lay people were not satisfied with such punishments because they often did not know about them.

Despite the concern for reform in the general cahier, no fewer than 46 of the 98 articles in the chapter on the clergy concern maintenance of clerical privilege. The strongest statement is found in article fourteen where the clergy said they rendered respect to Louis XIII not because of duty or royal prerogative but because they chose to do so.

The concern for liberties and privileges is found in most governmental, bailliage, and local cahiers. For example, the canons of Saumur said, "that the priests and gens de l'Eglise be maintained and guarded in all their immunities and liberties." Their colleagues in Bar-sur-Seine wanted to make sure that ecclesiastics kept "all the privileges, immunities, and liberties granted to them from the beginning of time." 23

In the question of definition of rights, as well as the enforcement of reforms, the deputies had no hesitation in calling upon the king to help. There was no disagreement with Trent here. The fathers of the council expected and called for support from rulers to bring reform. Both deputies and fathers, however, wanted the king to be guided by the clergy. The local, bailliage, and governmental cahiers for the First Estate also make clear the clerical conviction that they were the first order in a society of orders because God wanted it, and that they had the duty to defend that position against all comers in matters of ecclesiastical jurisdiction, status, and privilege. ${ }^{24}$

Further perspective on the clergy's view of privilege is found in comparing the 1614 general cahier of the First Estate and the decrees of the Council of Trent. There are two significant differences. Both concerned what the French clergy would call privileges, but what

${ }^{23}$ Archives Départementales (hereafter AD), Maine-et-Loire IBG, no. 4; AD, Saône-etLoire C 505, no. 31.

${ }^{24}$ See, for example, the cahiers of the chapters of Saumur, AD, Maine-et-Loire IRG, no.4; and the cahiers of the clergy of the Bailliage of Troyes, AD, Aube G 140. 
Rome considered to be abuses. These were in commendam benefice holding and the so-called Gallican liberties.

The practice of in commendam benefice holding to permit the diversion to the secular clergy of what was regarded as excess monastic wealth gained the approval of the papacy in the fourteenth and fifteenth centuries, because in commendam abbots and priors held their position without being members of the religious order concerned. ${ }^{25}$ In reality the practice made the already affluent segment of the secular clergy more wealthy. It also led to financial difficulties for the religious houses and to lack of religious discipline.

The Council of Trent had addressed the problem in its reform decrees as early as 1547, but had insisted only that abuses be curtailed through the appointment of competent vicars to fulfill the duties of the in commendam holder. This was still the case as late as 1562, when bishops were instructed to visit abbeys and priories held in commendam. Then in 1563, in the last set of decrees, the Fathers of

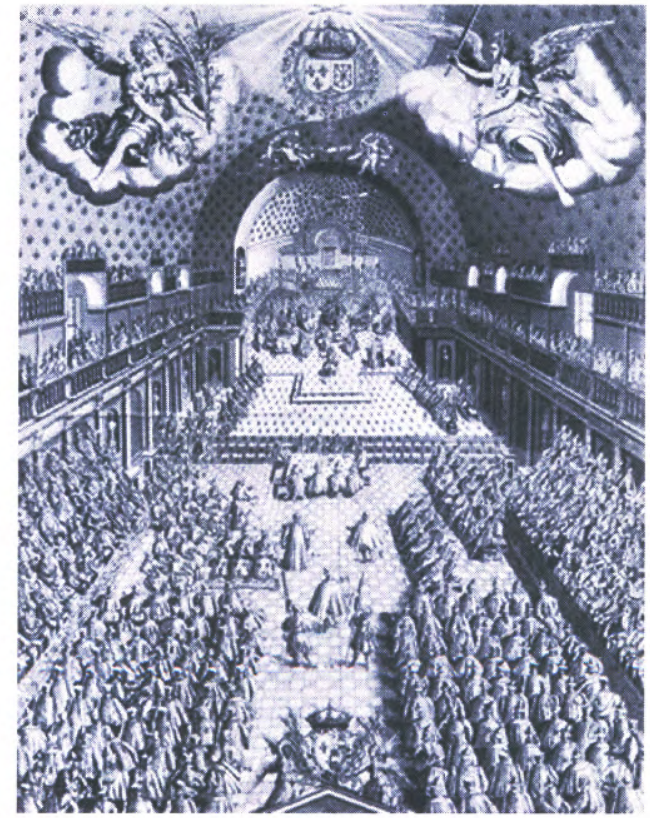

The Estates General of 1614.

Collection of the Bibliotheque Nationale, Paris, France

${ }^{25}$ Fr. Olivier-Martin, Histoire du droit français des origines à la Révolution (Paris, 1948), 470-71. These men were usually not resident. 
Trent had a change of heart and called on the pope to end the practice "according to his piety and prudence ... so far as he sees the times will permit." 26

The deputies to the Estates General of 1614 ignored this last minute tentative attempt at reform of the Fathers of Trent, even though Bishop Camus chided them about it. In his Homélie des désordres des trois ordres de cette monarchie, preached on 8 February 1615, he said:

Is it not a monstrosity to see seculars commanding regulars, those who carry the weight of the day and the heat, while the others, without doing anything, have all their honor and substance? Is this not to reverse all order and to have a cavalry troop commanded by an infantryman ${ }^{27}$

The clergy of the Bailliage of Bar-sur-Seine had a strong statement against the practice in their cahier, and their deputy to the Estates General, a member of the Trinitarian Order, managed to convince his fellow Burgundians (which included Camus) to insert a slightly weakened version in the governmental cahier. ${ }^{28}$ Matters went no further. The general cahier was silent on in commendam benefice holding. The reason is easy to find. Thirty-five percent of the votes in the general assembly were cast by in commendam abbots or priors. Many of these deputies were also bishops strongly committed to the reform of the church. There were limits, however, and excuses could be found: one had to have sufficient income, it was a matter of custom, and so on. Tillich's insight is of use here. In a world in which religion was coming to occupy only a part of existence, even a sincere reformer could allow himself to participate in the material rewards of his state of life.

The other major difference between the clerical cahier of 1614 and the decrees of the Council of Trent regards the so-called Gallican liberties. Here too Tillich is of use. The Gallican liberties were a series of exemptions and privileges that began with the right of the king to choose bishops and the holders of various other benefices and

\footnotetext{
${ }^{26}$ H.J. Schroeder, O.P., ed., Canons and Decrees of the Council of Trent (St. Louis, 1941), 55$58,141,230$.

27 Camus, Homélies, 304.

${ }^{28}$ AD, Saône-et-Loire C 505, nos. 16, 31.
} 
included most things that French clerics could claim were traditional. The first article of the general cahier of the First Estate put it well:

That the universal and ecumenical Council of Trent be received and published in your kingdom and the constitutions of it guarded and observed, always without prejudice to the rights of Your Majesty, the Liberties of the Gailican Church, privileges and exemptions of chapters, monasteries, and communities. His Holiness shall be asked that these privileges, liberties, and exemptions be observed and remain in their entirety without this publication prejudicing them. ${ }^{29}$

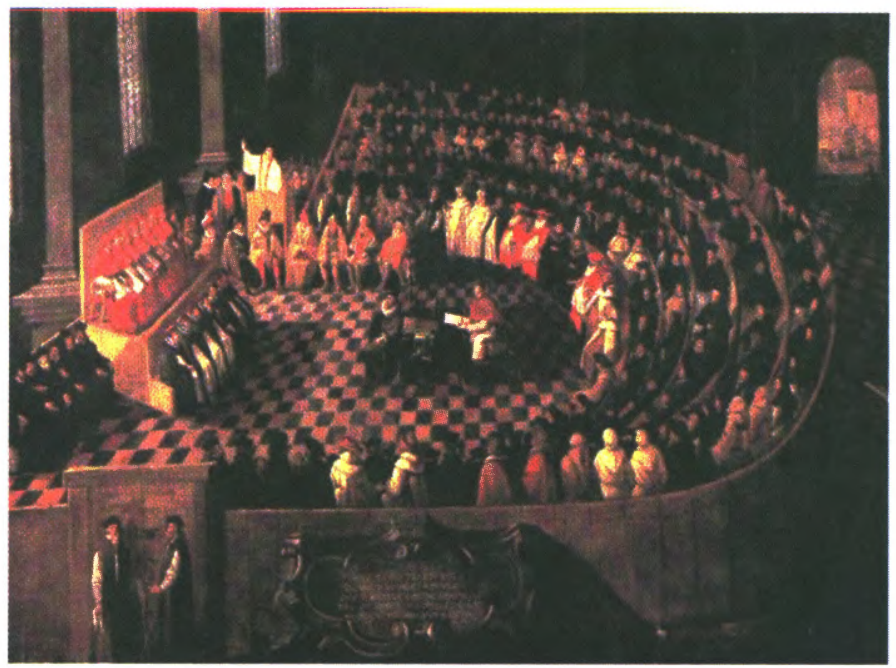

The Council of Trent. Period painting. Public Domain

The question of the king's acceptance of the Council of Trent for all of France was raised early in the meetings. There was significant (though not unanimous) support for this in the local cahiers. Under pressure from the reforming bishops, agreement to recommend acceptance to the king was reached on the same day the matter was initially raised.

${ }^{29}$ Cahier des remonstrances, 4 . This comes at the end of a long general first article, but it was underlined. 
The first item of business on the next day was brought forward by "des sieurs deputés des chapitres et autres de l'inférieur ordre." These deputies insisted that the wording on Gallican liberties be included. The other deputies agreed. There was definite support for this in the local cahiers. It would have been hard for the deputies of the First Estate to resist supporting the statement that reception of Trent should not endanger "other privileges ... which they enjoyed at present as well as those graces and dispensations heretofore obtained." ${ }^{30} \mathrm{~A}$ good cover, indeed, for in commendam benefice holding.

There were many variations on the theme of clerical selfperception, particularly by ecclesiastical rank. For example, bishops and chapter members had significantintly different ideas about power within the diocese. Perception also varied according to position on reform. Reformers had a good view of themselves and a bad view of others, even though they shared some of the faults of those they criticized, especially in commendam benefice holding. Self-perception was also influenced by social rank, relation to other clerics, and education and experience. ${ }^{31}$

When bishops dominated the process of cahier writing, the tendency was to emphasize the reforms of the Council of Trent and to sympathize with the problems of the rural clergy. When chapter members dominated, the tendency was to emphasize Gallican rights and to ignore the plight of the ordinary parish priest. ${ }^{32}$ Chapter members, in general, were not involved in parish work and saw themselves as an elite group.

The few governmental, bailliage, and local cahiers of the First Estate that still exist are more critical of clerical life than is the general cahier. The latter was primarily concerned with the general rights and privileges of the clergy and implied that the laity should allow the clergy to apply the reforms of the Council of Trent as they saw fit. This would include reforming the clergy, of course. But it was not seemly, in the opinion of the deputies of the First Estate, to admit the nature or scope of clerical abuses or to let the other estates get too involved in discussing such matters.

${ }^{30}$ Lalourcé et Duval, eds. Receuil de pièces originales et authentiques concernant la tenue des Etats généraux (Paris, 1789), 6:93-95 (7-8 Nov. 1614).

${ }^{31}$ Hayden, "Social Origins," 31-40.

${ }^{32}$ The cahier of the clergy of the Bailliage of Troyes is an exception to the latter statement, AD, Aube G 140. 
When rural parish priests were mentioned in the general and local cahiers, they were presented as poorly educated and poorly paid, sometimes as leading immoral lives and as living at the mercy of nobles who interfered with their clerical duties. No mention was made of the fact that poor pay was at least partly the result of the benefice-holding policies that syphoned off local church revenue for the benefit of the city clergy, including many of the deputies to the Estates General.

The governmental, bailliage, and local cahiers of the First Estate do not spell out in any detail the personal faults of the rural clergy, except for the few that emphasized concubinage and lack of education. ${ }^{33}$ The general cahier of the First Estate leaves the impression that the elite clergy had little understanding of the lives of the rural clergy. This is borne out by the fact that of the 59 bishops at the Estates General of 1614 , only sixteen seem to have personally carried out a pastoral visit to rural parishes before the meeting of the Estates General ${ }^{34}$.

The bishops at the Estates General were reformers. For example, 44 percent of them published synod statutes, while only 22 percent of the other 49 French bishops of 1614 did so. ${ }^{35}$ But holding synods and other reforming activities, such as building seminaries and sending missionaries to country parishes, was effort directed from the city outward.

Not all of the variations in self-perception can be determined through the documents connected with the Estates General of 1614. The deputies to the Estates General included bishops, chapter members, diocesan officials, curés, and male religious, but it did not

\footnotetext{
${ }^{33}$ For education, see AD, Puy-de-Dôme 2 G 746 (art. 23 of the cahier of the Diocese of Clermont). For concubinage, see AD, Saône-et-Loire C 505, nos. 16 and 17 (cahiers of the Government of Burgundy and the Bailliage of Mâcon, 10r), both of which refer to "many ecclesiastics" having concubines. A comparative study of synodal statutes is providing insight in this area.

${ }^{34}$ Répertoire des visites pastorales, vols. 1-4, passim. There were many pastoral visits which are known to have taken place but for which records no longer exist. For the period before 1614 this does not seem to have been the case for any of the bishops at the Estates General except Cardinal de La Rochefoucauld of Senlis, formerly of Clermont, and Armand Jean du Plessis of Luçon, the future Cardinal Richelieu. See Joseph Bergin, Cardinal de La Rochefoucauld (New Haven, 1987),109-10, 115; and Bergin, The Rise of Richelieu (New Haven, 1991), 88, 91-92.

35 A. Artonne et al., Répertoire des statuts synodaux du diocèses de l'ancienne France du Xllle à la fin du XVllle siècle, 2nd ed. (Paris, 1969), passim. See also Hayden, Estates General, 92, and "Social Origins," 33-35. Undoubtedly, some statutes were published which are now unknown, but there is no reason to believe that the number was large or that their existence would change the ratio of publication between the two groups.
} 
include vicars, habitués, brothers, nuns, or sisters. Further, the cahiers do not reflect many of the concerns of curés, especially rural ones. This is where the study of the other clerical records mentioned earlier is of use.

Despite all the variations and limitations, a clear picture emerges. The city clergy, mostly bishops and chapter members who dominated the Estates General, emphasized the importance of male clerics in all spiritual matters and ceremonies. There was no place for peasants and their participatory nature religion. In addition, the clergy were presented as the only ones with the ability and the right to discuss and decide theological matters, including censorship.

The clerical elite believed that they had the aptitude and training to participate in the governance of the country. They also maintained that they were owed special places in the parlements and on the king's councils. In short, the clergy saw themselves as the most important and best trained subjects of the king.

The deputies of the First Estate in 1614 wanted to maintain and extend their privileges and powers while restricting the roles of the laity and reforming the rural clergy. Their church was national, not local, controlled by the city clergy, and very interested in this world.

\section{Second and Third Estate Perceptions of the Clergy}

To understand Catholic Reform and its effects, it is important to know the views of the members of the Second and Third Estates on the clergy. The cahiers of 1614 provide a means of understanding what a significant segment of the nobility, and the officer/bourgeois elite of the Third Estate, thought about the clergy.

The traditional importance of the church from the lay perspective is implicit in the organization of the cahiers. Usually the section titled "Eglise" or "Clergé" is the first of the major categories of grievances. Further subdivisions under the ecclesiastical heading vary, and some are extensive. These include, after direct comment on the clergy and the church proper, sections on "hospitaux, maladeries et leproseries," and in many cases, on universities.

The necessity for, and the essential unity of, the First Estate/ ecclesiastical state was assumed in the lay cahiers, but the function of its members raised questions. Members of the clergy were seen as primary agents of moral surveillance; as teachers; as property holders and managers; as demographers and statisticians; as employees and 
employers; as dispensers of a wide range of social services, whether medical, notarial, educational, judicial or hospitable. At times they were considered to be a species of the genus that preoccupied many critics of French government - venal office holders. Moreover, there are dear implications that clerics were regarded as cultural guardians, not only of the sacred in a religious sense, but also in a way, one could argue, of "Frenchness."

The portrait of the clerical order that the lay cahiers describe is complicated by two internally contradictory elements. The first is that while the lay deputies regarded clerics as belonging to a juridically, customarily distinct group, the distinctions of the temporal social order were not considered to be erased by vows or tonsure. The second contradiction is that although the deputies demanded proficiency in the great array of functions described above, they also wanted a clergy more limited in their "liberties" and submissive to lay authority. Here the cahiers of the Second and Third Estates directly opposed the insistence of the clergy that the king recognize that they deserved a greater role in government.

The arrangement and the range of grievances in the cahiers of the Second and Third Estates imply the existence of an existing society and an underlying mental structure. The substance of the grievances, however, indicates the vector of lay opinion toward significant modification, not of the society, but of the mental structure.

With each of the two estates there was little disagreement between the final general cahier and the governmental cahiers. This was especially true in the Second Estate, where articles from government cahiers not put into the body of the general cahier were added as an appendix. Isolated striking variations from the norm (such as calling for election of curés in the bailliage of Vendôme and in one village in Champagne) exist in the local cahiers of the Third Estate, but the similarity of outlook and program of reform is clear. ${ }^{36}$

The cahiers of the Second Estate at all levels emphasized benefice reform, noble rights to church positions, the duties of bishops, and abolition of payments for administering sacraments or assisting at burials. The Third Estate cahiers placed relatively more emphasis on moral and intellectual reform of the curbs, record keeping, property

${ }^{36}$ For a full discussion of the content of the general and other cahiers, see Hayden, Estates General, 174-218. 
rights, and the rights of Frenchmen rather than just nobles, to church positions.

The 69 cahiers of the Third Estate of the bailliage of Troyes disagree about clerical abuse. ${ }^{37}$ In ten cahiers the curés were accused of not fulfilling their pastoral duties. In seven concubinage was the major issue. Other common complaints about the clergy included charging for services, hunting, and frequenting of taverns. Five cahiers contained wide-ranging thorough condemnations of clerical misbehavior. Eight cahiers had strong words about a number of abuses, while seven contained milder remonstrances of a general nature. On the other hand, 34 of the cahiers do not mention the clergy at all. Several of the cahiers of the thirteen towns of Basse Auvergne have a general statement about needing better clergy. Here, though, the major concerns were the bad weather of the previous winter, poor crops, isolation, and the destruction left over from the Wars of Religion. ${ }^{38}$ Nevertheless, it is primarily in Basse Auvergne and the Troyes region that the grievances of the peasants surfaces. ${ }^{39}$ These include, at times, nonresident, hunting, and immoral priests, although poor crops, bad roads and high taxes were more important. The peasants seem to have been more upset by bureaucrats and bourgeois than by their priests.

It becomes apparent to the reader of the lay cahiers that there were some differences of opinion between the two lay estates concerning the First Estate. But the basic homogeneity of the lay cahiers on this topic, unlike many others, within and between estates, makes it feasible to treat them together. Differences in content, tone and approach will be noted in the process. The lay deputies to the Estates General of 1614 were often fulsome in their declarations of the importance of the First Estate. The ceremonious piety is especially marked in the case of the noble cahiers. The nobles of Beauvaisis said that they were starting their cahier with the church:

\footnotetext{
37 Durand, Cahiers de doléances, 77-289.

${ }^{38}$ AD, Puy-de-Dôme 5 C Aa 3rr.

${ }^{39}$ The other major sources for peasant sentiment are the cahiers of the parish of Colombes, Archives de Paris D 2B2; the town of St. Cyprien, AD, Dordogne 6 C 1; and the Beauvais region, Bibliothèque municipale (hereafter BM). Beauvais Collection Bucquet aux Cousteaux, LXXXVI, 665-88. For a full discussion of peasant grievances, see Greenshields, "The Relations of Sentiment," 49-61.
} 
which has taught us to thank God for the infinite blessings that we receive from his divine goodness, even to observe all that is required to obtain the things necessary to the good of our salvation, it is right that the Catholic Religion be reverently and inviolably preserved in this Realm where from time immemorial it has shone in such splendor that our Kings have been honored with the most precious and venerable title of "tres Chrestien" and with being the first son of the Catholic Church.... ${ }^{40}$

The end of this sentence, after some nine more lines, is a request that clerics and religious reside in their benefices. Other cahiers carried on in a similar vein, the nobles of Lyon for example, opening theirs with an assertion that "piety is the principal foundation of a state." The architectural metaphor was common in these matters, but more often it was applied by the noblesse to itself rather than to the church. Norman nobles were "le principal apuy de vostre couronne," while those of Orléans were "la principalle colonne de l'estate;" and the nobles of one bailliage in Champagne decided that they were both "appuy" and "colonne." 41

Whatever the metaphor, all true gentilshommes agreed that blood, "le sang pur," was what fundamentally distinguished them from others and qualified them for leadership in both state and church. ${ }^{42}$ Although eager to demonstrate their piety in affirming the importance of the church, they seldom forgot their own intrinsic, inherited greatness. In fact, the authors of some cahiers argued that piety was an integral part of the illustrious noble heritage. The nobles of Orléans pursued this argument ingeniously in their cahiers, combining tales of ancient martial courage with accounts of zealous devotion to the faith. ${ }^{43}$

By contrast, the cahiers of the Third Estate started with avowals of loyalty to the crown. They then usually proceeded without

\footnotetext{
${ }^{40}$ BN, Collection Clairambault (hereafter Clair) 742, 17-18.

${ }^{41}$ Lyon: BN, MSS f.fr. 4782, 1r. Normandy: BN, MSS f.1r. 4083, 10r. Orléans: BN, MS Clair 742, 61. Nobles of Chaumont-en-Bassigny: BN, MSS n.a.f. 2808, 2r

${ }^{42}$ For an extensive discussion of noble theories of superior blood, see André Devyver, Le Sang épuré: Les Préjugés de race chez les gentilshommes français de l'Ancien Régime, 1560-1720 (Brussels, 1973).
}

43 BN, Clair 742, 29-30. 
ceremony to the itemization of grievances. The two most frequent adjectives used to describe the acceptable cleric are "suffisans" and "capables." At first glance, then, the ideal priest described by the Second and Third Estates was close to the ideal of the First Estate. But these generalities covered a multitude of virtues, and some cahiers enumerated them quite extensively. The Third Estate cahier from Reims indicates that its authors knew exactly what they wanted in candidates for vacant benefices:

capable persons, known au pays, of good life, morals and conversation, who have studied humane letters sufficiently and at least a year of philosophy, which they should be able to prove by a certificate from those under whom they studied. By preference the said cures should be conferred on those who have carried out such studies in the said seminaries. ${ }^{44}$

Not all were as educationally demanding as the deputies in Reims, who also enjoined bishops to make sure that there were good preachers and real "théologiens" in the cities. But in almost every cahier, both noble and roturier, from a wide range of areas both rural and urban, the authors seem to have been looking for the same men to fill vacant benefices, "learned and virtuous persons" distinguished by "bonne moeurs et doctrine," men "de conscience, de scavoir et de probité," persons of sufficient "aage et prudhomie." The Third Estate of Anjou was especially eloquent on the necessity of recruiting the best men possible to be priests and prelates, "good and diligent pastors who by the virtue of their doctrine and the example of their piety can re-erect what has fallen, strengthen that which has been shaken, and clarify that which is obscure." Later on, the cahier reiterated the call for "personnes de saincte vie et de doctrine suffizante, capables de prescher et anoncer la parole de Dieu." ${ }^{45}$

While the general descriptions of virtue seem almost formulaic at times, the deputies proceeded to demonstrate more specific qualifications for those who would be priests and prelates. One pervasive demand was that they be Frenchmen of legitimate birth.

\footnotetext{
44 BM, Reims MS 1700.

45 A. Meynier, Cahiers des gens du Tiers Etat au pays et duché d'Anjou en 1614 (Angers, 1905), 34-35.
} 
In the case of foreign religious orders, one noble cahier demanded that their houses in France be visited by French, preferably noble, guardians every three years. As the First Estate cahiers did, the lay cahiers wanted priests who "had the charge of souls" to speak the local idiom. As one might expect, one of the strongest statements on this question came from the Breton cahier. Some went even further in the matter and demanded that preference be given to inhabitants of the diocese where the benefice was located. ${ }^{46}$

Significantly, the authority referred to in these instances was the Ordinance of Blois. ${ }^{47}$ While the deputies of the Second and Third Estates would occasionally make vague reference to the "Saincts decrets," and once to the Pragmatic Sanction, ${ }^{48}$ their standard recourse was not to Trent but to past French ordinances, many of which were responses to the cahier of previous estates General, and particularly those of Orléans (1560) and Blois (1576). Although in someways the deputies had clearly caught the Tridentine spirit, the Council of Trent had no authoritative role in their cahiers. This absence was related to a larger Gallicanism that can be seen in other preoccupations of the cahiers, such as the condemnation of the annates paid to Rome. ${ }^{49}$

While they agree on many of the basic attributes of the "bon pasteur" (after all, who would not have done so?), the cahiers of the Second and third Estates differ in their view of one principle that permeates the grievances of all orders: that is, the concern with precedence. It affected both lay orders, one could even argue equally, but the nobles anxiety is the more obvious. For while nobles theoretically held the position that considerations of morality and competence were paramount, they also wanted more: more benefices, more education and opportunity for their children, more control over the disposition of this wealthy and influential sector of the nation. This demand for precedence seems to be another form of the noble longing for the venal offices which they hated so much and for which they felt themselves to be the natural candidates.

\footnotetext{
${ }^{46}$ Beauvais: BN, Clair 742, 54-55, Brittany. BN, MSS f.fr. 4782, 32v. See also Lyon, ibid.,

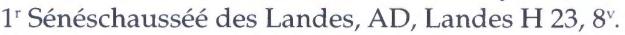

${ }^{47}$ In this case, article 4, which forbade ecclesiastical preferments of archbishops or bishops to anyone who was not French. François Isambert, Receuil général des anciennes lois françaises (Paris, 1892), 14:383.

48 Third Estate of Reims: BM, Reims MS 1700, par. 3.

${ }^{49}$ Nobles of Lyonnais: BN, MSS f.fr. 4782, $5^{\text {r }}$.
} 
The noble demand for precedence in religious matters emerges in many specific ways. There are, for example, the demands for exclusivity in the Society of Saint John of Jerusalem, whose members were to have at least three "races" (generations) of nobility. ${ }^{50}$ There are also the requests for quotas of gentilshommes in appointments to cathedral chapters, even a suggestion that one-third of the places be reserved for nobles. An alternative recommendation was that all other things being equal, noble candidates had to receive preference in the award of all benefices. Moreover, the Second Estate wanted abbots to be noble, and in cases where the abbey was a noble foundation for nobles there was to be stricter surveillance to make sure that the founder's intention was honored. Likewise were the schools, whose establishment the cahiers encouraged, to reserve some of their places for the children of poor noble families. ${ }^{51}$

In their consideration of ecclesiastical matters the Third Estate's desire for precedence is expressed more subtly - but more pervasively - in the cahiers; it is also a desire shared in an indirect way by noble deputies. It occurs wherever there is a question concerning the regulation of the performance of clerical duties, especially those that involve contentious issues of property. It also holds true for the punishment of serious moral lapses. In these cases, whether they deal with the management of hospitals, ecclesiastical woods, the maintenance of parish registers, or the prosecution of clerical crimes, the concluding assertion is almost invariably the same. Where there is contention or possible malversations on the part of clerics or religious, the matter must be taken up by lay authorities for resolution or the enforcement of statutes. In their preference for lay authorities, Third Estate cahiers usually specify royal judges, most of whose social origins were similar to those of the deputies. Nobles also make mention of baillis and sénéchaux, who would have had the necessary "weight" where offenses committed by prelates were at issue. This tendency in the lay cahiers is the most significant divergence of opinion from those of the First Estate. ${ }^{52}$ The lay orders thus established criteria for the recruitment and satisfactory performance of the clergy. In addition to requirement of the general characteristics of probity, ability,

\footnotetext{
50 Nobles of Champagne: BN, MSS f.fr, $4782,51^{\mathrm{v}}$.

${ }^{51}$ Nobles of Orléans: BN, Clair 742, 53, 59. Poor families were those with less than 1200 livres annual income.

52 Third Estate of France: AN, K674, no. 15, $8^{\mathrm{v}}, 13^{\mathrm{r}}$. Nobles of Champagne: BN, MSS f.fr. $4782,48^{v}$; Nobles of Picardy, ibid., $84^{v}$, 85v ; Nobles of Guyenne: ibid., $106^{\mathrm{r}}-108^{\mathrm{v}}$.
} 
knowledge, and capacity, there was an itemization of specific tasks that had to be carried out effectively and of specific manifestations of virtue, or at least of a lack of vice, in daily life.

In the main, the list of qualifications and tasks specified by the various lay cahiers would have pleased the Fathers of Trent. The recruit was to be a Frenchman in his early to mid-twenties, depending on the nature of the benefice (the age requirements in these cahiers were similar to those specified by the First Estate); if possible of local origin or at least someone from the region if not the diocese; preferably seminary trained (the Second and Third Estates seem to have been as eager as the First to encourage the foundation of more seminaries); and certainly knowledgeable in sound doctrine and "letters." He had to be a mature person of good reputation and good conversation. This last term was most important, because in 1614 it meant the ability to get along and live well with other human beings..$^{53} \mathrm{He}$ had to maintain a respectable appearance, which included clothing - "habits decents selon leur profession" - and modesty in the style of hair and beard. ${ }^{54}$

The new recipient of a benefice had to be resident there, had to have received it in the proper way, on his merits, and the benefice itself had to provide a sufficient living. If cures were too poor to provide for a priest, then the bishop should amalgamate or subsidize them. At the same time, however, a village of thirty souls should at least have a vicaire to care for them. Benefices which were "too" rich should be supporting the poor, schools, hospitals and the like.

The new recruit, now resident in his benefice, had much to do, in the opinion of the deputies. He had to administer the sacraments regularly, teach catechism twice a week, and perhaps teach other things as well; report all births, marriages, and deaths in his domain and preside over the rites associated with each. There may also have been foundations requiring masses in his church. Moreover the moral and spiritual life of the parish were in his hands and he had to chasten, correct, discipline, and, in serious cases, report those who

\footnotetext{
${ }^{53}$ John Bossy discusses the use of the English word "conversation," which in the fifteenth century meant "the state of living or behaving in an environment of other persons." Christianity, 168.

${ }_{54}$ Third Estate of France: AN. K 674, no. 15, fol. $6^{\mathrm{v}}$. The deputies requested that secular or regular clergy who did not observe these requirements be brought before royal judges and imprisoned. The Third Estate cahier of Touraine, among others, made the same request. Charles de Grandmaison, "Doléances du Tiers-Etat de Touraine aux Etats généraux de Paris, 1614," Bulletin de la Société archéologique de Touraine 8 (1889-91): 44.
} 
transgressed. His was also often the stewardship, even if indirectly, of considerable property, something in which the authors of the cahiers took a particularly keen interest.

The church and the presbytery were, in many cases, only the center of the priest's patrimony, although their maintenance was often a principal point of interest to episcopal visitors. There was also the cemetery, where one had to keep order and try to bury the dead whose relatives usually wanted them in the church, as close to the altar as possible, so much so that one noble cahier insisted on reserving the choir for the bodies of the nobility. ${ }^{55}$ In addition there were sometimes fields and forests attached to a benefice, and these too required management and vigilance. Aside from these considerations, there was the matter of the tithe; a point of contention in the parish and sometimes a cause of violence, it always required vigilance. ${ }^{56}$

Although the deputies of the Second and Third Estates did not say it, it is hard to escape the impression that the humbler sort of priest was very much "of the people," jostling for precedence, respect, income, and survival in a world where these were scarce and precious commodities. The cahiers are not reticent to say that clerics often had other official duties to perform which, although they garnered a modicum of respect, scarcely endeared priests to parishioners. Representative of the clerics' role as agents of royal justice were the lettres monitoires read from the pulpit, admonishing those with knowledge or culpability in criminal cases to come forward and declare what they knew under the threat of severance from the sacraments.

Why were deputies so interested in the minutiae of religious life? If we take their stated reasons, there are two. Firstly, they thought the salvation of their souls and their escape from divine wrath depended on the adequate performance of the clergy. Secondly, they thought the clergy were not doing the job. Of the results of such a failure there was little doubt. Impiety among the religious needed

\footnotetext{
55 Nobility of Guyenne in BN, MS fr. 4083, $108^{\mathrm{r}}$.

${ }^{56}$ For seventeenth-century Auvergne, for example, evidence of violent tithe disputes between priests and laymen can be found in the criminal justice archives and the records of the maréchaussée (police). For noble disputes with clergy, see, for example, "Procès verbaux des Vice-baillis" for 4 Aug. 1609 and 9 Oct. 1628 in AD, Cantal, Fonds de Comblat, and the complaint of a curé against a noble family of 26 Sept. 1634 in "Présidial d'Aurillac" in AD, Cantal IB 922. For a detailed account of such a dispute between peasants and clergy, see the case of 7 Aug. 1654 in ibid., 1 B 924.
} 
remedy, said the nobles of Beauvaisis, in order to avoid the wrath of God, which grows daily, "a cause du ... desordre et mepris." 57 Bishop Camus could not but have added his own "amen." Reforms were necessary, according to the nobles of Lyon, in order to remove the pretext for schism, because "it seems that the first pretext of those who have separated themselves from the church is based on the so-called 'mauvaise vie' of those who have ecclesiastical charges."58 Many cahiers from both estates published a list of sins generally affecting France, perhaps the better to show the damaging results of impiety in the church and the related lack of instruction which could provide "tant de biens et advantages aux republiques ... en assistans les bons et chastiens les pervers." 59

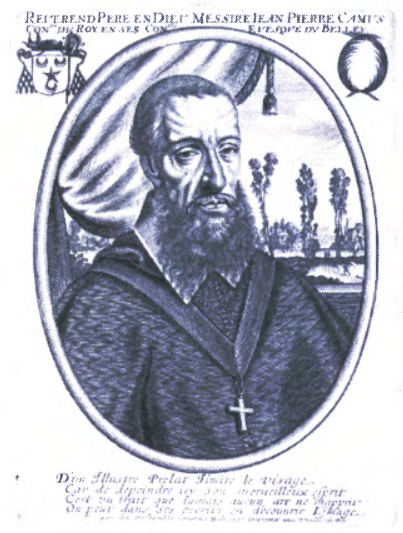

Jean-Pierre Camus, bishop of Belley.

Collection, Bibliothèque de Bourg-en-Bresse

What was it exactly that needed reform among the French clergy? Where were the clergy failing? To these questions there was no shortage of answers and no reticence about suggesting remedies. While acceptability could be simply stated, the unacceptable required much more detail. Here the lay deputies were much more punctilious than their ecclesiastical counterparts. The evils besetting the clergy

BN, Clair 742, 18.

${ }^{58} \mathrm{BN}, \mathrm{MS}$ fr. $4083,2^{\mathrm{r}}$.

${ }_{59}$ Nobles of Beauvais: BN, Clair 742, 22. It is interesting to note that these noble deputies saw the Catholic Reform primarily as a way of fighting the new heresy that had so divided France. 
were the more detailed reverse of the chorus of virtues sung by the lay deputies. To some extent these problems can be divided into, on the one hand, administrative, systemic ills such as confidence, commendatory benefice holding, and the granting of indults, and on the other hand, matters of individual behavior and ability such as concubinage, drunkenness, and ignorance, although these categories are not mutually exclusive.

In contrast to the clerical delegates, deputies of the two lay estates of ten gave pride of place to two interrelated practices: plurality of benefices and non-resident beneficiaries. These in turn were related to other pervasive problems including simony, confidence, and commendatory benefices. The Third Estate of Anjou, in its first sentence on the church, denounced all the practices that had allowed corruption and disorder to flourish where piety had previously reigned: "simony, confidence, plurality of benefices in the same person." The deputies complained that grievances had been made against these practices at the Estates of Blois and Orléans, but that the resulting ordonnances had not been obeyed..$^{60}$

The consequences of this disobedience were "le désordre et la corruption croissant en l'église gallicane." One could now find cathedrals in the hands of children, which were thus deprived of necessary pastors. Others were in the hands of prelates not because of merit but "par faveur, ambition et simonye." ${ }^{161}$ To the dismay of lay deputies, these bishops were excused from preaching, from residence in their diocese, and from episcopal visits to its churches. Moreover, they had spread the simoniacal corruption, selling benefices and ecclesiastical offices for a share of their earnings. One could also find abbeys possessed by gentilshommes and other laymen, "mesme non catholiques;" even women possessed abbeys "soubs le nom d'occonomes ou de commandataires." The results were that abbeys which had been "maisons de piété et de saincte vie, les escolles de scavoir," had degenerated for the most part into "retraites de soldats et cloaques de tous vices, ordure et pollution." Rather than living an edifying life, many members of the secular clergy were profaning the "saincts revenus" in dissolute luxury while the poor were dying of hunger at the very gates of the bishoprics. These abuses had excited

${ }^{60}$ Meynier, "Anjou," 32.

${ }^{61}$ Ibid., 33. 
the wrath of God and had permitted the birth of "l'hérésie, les séditions et tumultes," as well as the conspiracies of the Catholic League, and had brought the monarchy within an inch of ruin. ${ }^{62}$

The themes of Anjou were developed, although usually with less eloquence and elaborate causation, by the other cahiers. All decried the frequency of non-resident benefice holders, although here the noble cahiers were sometimes more lenient: the nobles of Orléans, for example, excepted beneficiaries who had been called away on legitimate royal service. ${ }^{63}$ Even these men, however, should only keep the benefices they needed. Other noble cahiers were less permissive. ${ }^{64}$

The sentiments regarding plurality of benefices were similar. ${ }^{65}$ The disapproval of this practice was also general but not unanimous - although it was applied to both prelates and parish priests - to secular and regular clergy. The nobles of Picardy, while asserting the customary demand for noble preference in the award of benefices, also acknowledged that in their province, being "fort peuplé" there were many curés who administered two cures or large cures in which there were two village churches. The gravest result was that some inhabitants did not receive the sacraments, especially that of baptism, with sufficient frequency. The solution proposed here was that if revenues were insufficient to maintain two curés, one of the churches had to be provided with a vicar capable of administering the sacraments. ${ }^{66}$ The First Estate deputies wanted benefice holders who were responsible for the care of souls to be resident. They were silent, however, about holding more than one benefice that did not have such a duty attached and about in commendam benefice holding.

In the cahiers of the Second and Third Estates the problems of non-residence and plurality were directly related to several other problems, especially those concerning methods of preferment and the sufficiency and direction of ecclesiastical incomes. This reality of the various means of acquiring and maintaining benefices was, according to the lay cahiers, vastly different from the ideal referred to above. Simony is the term that most completely describes the complaints on these matters, although it was a word often used in the cahiers in the more restricted sense of charges for the administration of sacraments.

\footnotetext{
62 Ibid., 34-35.

${ }^{63} \mathrm{BN}$, Clair 742, 54.

${ }^{64}$ See the nobles of Beauvais (BN, Clair 742, 17) and Lyonnais (BN, MSS f.fr. 4083, $2^{v}$ ).

${ }^{65}$ BN, Clair 742, 19; BN, MSS f.fr. 4083, 2r.

${ }^{66} \mathrm{BN}, \mathrm{MSS}$ f.fr. $4782,84^{\mathrm{v}}$. BN, MS fr. 4089 , $\mathrm{e}^{\mathrm{r}}$. AD, Landes, H 23, $7^{\mathrm{r}}$.
} 
The nobles of Beauvaisis complained that throughout the ecclesiastical hierarchy, from the episcopacy to the ordinary curé, no spiritual service was performed any more unless it was done for money; and theirs was only one of many such complaints, which were supplemented by the requests that burials and the administration of sacraments be free of charge as specified by the Ordonnance of Orléans ${ }^{67}$ This was a widespread request but was also contrary, as one cahier pointed out, to the Ordonnance of Blois ${ }^{68}$ The Third Estate of Touraine took another common approach, which was to demand some free services and a set of fixed, posted prices for others. These principles also applied to the charges for ecclesiastical justice and administrative acts. ${ }^{69}$

The attitude to simony in ecclesiastical preferments was generally condemnatory. The nobles of Lyons complained of the "sy vilane et abominable moiens" by which ecclesiastical charges were conferred (although in keeping with the theme of other noble deputies, they concluded by demanding that one solution was to offer half of the places to nobles of three races on the father's side in all cathedral churches, abbeys, and priories), and these sentiments were shared by most noble cahiers. ${ }^{70}$

The practice of simony was condemned directly by calls for prohibition of payments to bishops for ecclesiastical appointments, for example, by the cahier of Brittany. As far as the upper clergy were concerned, some cahiers also demanded that archbishops, bishops, and other important ecclesiastics be named according to the procedures set out in the royal ordinances. The general cahier of the Third Estate provides an example. In keeping with that estate's demand for the supremacy of temporal over ecclesiastical authority, the cahier of Landes wanted contested benefices to be conferred by the sénéchaux. ${ }^{71}$

The matter of simony in all its aspects was, of course, related to that of irregularities and inequities in ecclesiastical income. Here the

\footnotetext{
67 Isambert, Receuil, 14:68-69.

${ }^{68}$ Beauvais: BN, Clair 742, 19. Third Estate of France: AN, K 674, no. 15, 5v. Third Estate of Reims: BM, Reims MS 1700, par 17. Third Estate of Chacenay in Durand, Troyes, 105. For Blois, see Isambert, Receuil, 14:395-96.

${ }^{69}$ Grandmaison, "Touraine," 45-46. Nobles of Picardy: BN, Mss, f.fr. 4782, 86. General cahier of Third Estate: AN, K 674, no. 15, 9r. Third Estate of Landes: AD, Landes H 23, fol. $6^{\mathrm{v}}$.

${ }^{70} \mathrm{BN}, \mathrm{MSS}$ f.fr. $4083,5^{\mathrm{r}}-5^{\mathrm{v}}$.

${ }^{71}$ Brittany: BN, MS 4782, 33r. General cahier of Third Estate, AN, K 674, no. 15, $2^{\mathrm{v}}-3^{\mathrm{r}}$. Landes: AD, Landes $\mathrm{H} 23,7^{\mathrm{r}}$.
} 
problem was a thorny one, for in confronting the issues of confidence and benefices held in commendam, deputies were dealing with important aspects of property and income, which affected laity as well as clergy. As one might expect, there was a range of opinions and a good deal of inconsistency on the matter. The nobles of Champagne, who expressed the correct concern for priests' insufficient incomes, simony and the "trafficq es benefices," requested only that nobles provided with benefices and priories be forced to provide "service divine." The nobles of Berry demanded that possession of benefices by laymen "par eux ou par confidence," be prohibited. Third Estate opinion in the general cahier was much more specific about the non-residence of "titullaires" and "perception des fruicts du benefice par personnes nobles." 72

Simony represented at least one of the seven deadly sins avarice, of which confidence and in commendam benefices were further aspects. But there were other sins besetting the church, and in one way or another, the lay cahiers could be said to have inveighed against them all; most certainly against lust, sloth, and pride. From the venal preferment of benefices and the sale of the sacred there proceeded a host of other evils. Ironically, perhaps, one of them was the poverty of the lower clergy, about which most of the cahiers complained; another was the clerical luxury and sloth that they decried even more. ${ }^{73}$

But poverty and ignorance were not sins, and luxury was not a sin that concerned the lay deputies as much as other more active vices. This fact is revealed by the frequent denunciations and prohibitions in the cahiers: against "haunting" taverns, gambling, running about the countryside, getting drunk in public, wearing "indecent" garments, litigating, and conniving to influence the wills of parishioners. ${ }^{74}$

Concubinage was on the minds of many deputies. Those of the Third Estate of Touraine, for example, emphasized that no woman suspected of "pudicité," nor any other females under fifty years of

${ }^{72}$ Champagne BN, MSS f.fr. 4782, 49 ${ }^{r}$, 50r. Berry: Leningrad, Saltykov-Shchedrin State Public Library, MS fr. II 79/1-2. Third Estate: AN, K 647, no. 15, 8v.

${ }^{73}$ The cahier of Orléans brings into relief this contrast between the wealth of the cathedral and collegial churches and the rural vicaires too poor to live "selon leur qualité," BN, Clair 742, 55-56. In Beauvais, beside ruin and neglect, the complaint was of income and "excessive expense," ibid., 18-19. See also Third Estate of Reims in BM, Reims, MS. 1700 , par. 29.

${ }^{74}$ The Third Estate of Blois, especially worried about wills and the abuses and frauds committed by priests and their notaries, proposed an elaborate preventive formula including witnesses and validated declarations by the testator (BM, Blois, BB 18, 12). 
age, should be allowed in the houses of priests. Regular clergy were not to be allowed the company of women of any age. The Third Estate of Agenais wanted legitimacy and rights of succession denied to all children fathered by priests. The nobles of Orléans named "lewdness," concubinage, indecent and dissolute clothes, dances, taverns, and weapon-carrying priests as part of the "vice" and "mauvaise vie" that were a "grande scandale" to respectable folk. ${ }^{75}$

Among the nobles, those from the governments of Orléans and Ile de France were the most upset by concubinage. Among the clergy the concern surfaced in Burgundy. In the Third Estate the bailliages of Touraine in Orléans and Troyes in Champagne were particularly upset. Does this indicate sporadic incidence or sporadic concern? Synodal statutes seem to indicate the former. Perhaps the answer to this question among the peasants is found in the remonstrances of the village of Bouilly near Troyes, which contained a very strong condemnation of clerical sexual abuses. What rankled most was that the women of the local clergy "portant grand estat voire plus que les femmes des melieurs laboureurs et marchand[s] du pays." ${ }^{76}$ Evidence of peasants being upset only when the curé's de facto wife lorded it over the women of the village is also evident in pastoral visit records. It remains to be seen whether early modern rural Catholics were more or less concerned about the women of priests who were an integrated part of their community than they were about non-resident benefice holders - the curés who rarely appeared, and then often only to collect the tithe.

The cahiers also expressed concern with "inappropriate" clerical behavior such as hunting, carrying arms, and involvement in commerce. The most frequent complaint in this last regard was that the timber belonging to benefices was being sold rather than used for the repair and maintenance of ecclesiastical buildings. With the mention of buildings we come to the sins of omission. Buildings were generally said to be in poor repair, parish registers and accounts were not up to date, and the services specified in some foundations were neglected. Hospitals and hospices were in a similar state. ${ }^{77}$

75 Grandmaison, "Touraine," 48. BN, Clair 742, 56-58. Georges Tholin, ed., Cahiers de doléances du Tiers Etat du pays d'Agenais aux Etats généraux 1588, 1614, 1789 (Paris, 1885), 16.

${ }^{76}$ Durand, Troyes, $87-88$.

${ }_{77}$ Reims in BM, Reims MS 1700, par. 33. Beauvais in BN, Clair 742, 20-21. Grandmaison, "Touraine," 46. Third Estate of France in AN, K 674, no. 15, 7, $10^{\mathrm{r}}$. 
The accusations against the secular clergy were also applied to regulars, although if anything, the disorder in abbeys and monasteries, according to the cahiers, was more scandalous. Commendatory abbeys with no real superior or absent superiors, "religious," and especially female religious, who were not properly cloistered, were all objects of lay opprobrium. Property was also at issue, and the disgraceful state of the temporal in the case of regular clergy was as bad as that in the secular clergy. ${ }^{78}$

Because the Catholic church in France was being led by men who sincerely wanted reform, it could be said that the Catholic Reformation was underway. At the same time it is apparent that, in the minds of the deputies at least, the clergy in 1614 were in serious need of reform. In that sense the reformation had not yet begun. There was agreement among deputies on some faults of the clergy, but substantial disagreement on the extent of those faults. The First Estate was generally less severe on its own members and tended to limit criticism to the lower clergy rather than including (as did the lay estates) the more exalted members of their order. A fundamental point of divergence occurred when deputies considered sources and remedies for clerical/religious problems. Clearly the clergy thought that abuses of privilege needed remedy, but that privileges themselves must be preserved intact. Lay deputies (and a few clerical reformers), on the other hand, often saw privileges themselves as the sources of problems.

The First Estate was insistent that it be permitted to clean its own house as it saw fit. The remedies proposed by the lay deputies were many and specific, but they were of two basic types. One was traditional, the other radically different. The desire for traditional reform - enforcement of ecclesiastical rules and regulations by clerics - is found in the repeated calls from every region for regular pastoral visits by bishops. The lay cahiers suggested that these be conducted free of charge on a regular schedule which ranged in intensity, some wishing annual visits and others demanding them at least once every three years. ${ }^{79}$ The other type of remedy, however, was of a very different nature. While the Second and Third Estate deputies

\footnotetext{
${ }^{78}$ Women religious were to be "fermées et grillées" according to deputies from the Lyonnais BN, MSS f.fr. 4983, 3. See also Beauvais in BN, Clair 742, 18-19.

${ }^{79}$ Lyonnais: BN, MS fr. 4083, 2v ; The Third Estate of France: AN, K674, no.15, 3' ; Reims; BM, Reims 1700, 1"; Anjou: Meynier, "Anjou," 33; Saumur: Revue historique, littéraire et archéologique de l'Anjou 1 (1867): 206-7.
} 
supported ecclesiastical reform by ecclesiastics and the traditional rights of the Gallican church, they reacted against attempts of the clergy to extend their dominion and tried to increase lay jurisdiction over clerical abuses.

Submission to temporal power ultimately involved a control of property as well as persons. In the cahiers the final and most drastic solution for clerical miscreants was usually the "saisie de leur temporel," an action pursued at a more gradual pace in so many other articles of the cahiers - those which demanded the review of accounts and the punishment of clerical misbehavior by lay authorities. The demand made by the Second Estate for more clerics from noble families suâs ân âttempt to enforce on clerics the rules of the lay social order. The call from both lay orders for the use of lay justice in punishing clerical crimes was, in part, a more specific case of this general tendency.

The attempts to extend lay control and impose lay standards on the clerical order were also the siblings of a growing mental exclusion of religion from certain aspects of life. The evidence of the cahiers supports the validity of Tillich's insight. ${ }^{80}$ By the early seventeenth century in the cities religion was becoming one of many activities rather than an integral part of all aspects of being and life. Religion was becoming regarded as concerned only with establishing a relationship with God and doing what was needed to get to heaven. Clerics, when not actually performing religious rites, were more and more regarded as part of secular society.

The cahiers of the clergy in 1614 show that city clerics, especially bishops, were contributing to the process by working to limit lay participation in the sacred. The bishops' program emphasized action by the diocesan clergy and, to a lesser extent, by members of active religious orders (by implication making action more important than contemplation and prayer). The bishops insisted that the parish clergy live separately and differently from their parishioners. They condemned a number of popular religious beliefs and practices as superstitions while insisting on regular performance of various formal religious duties.

The peasant majority and their parish clergy, almost unrepresented at the Estates General of 1614, were major targets of

${ }^{80}$ See also Stuart Clark, "French Historians and Early Modern Popular Culture," Past and Present 100 (1983): 62-99. 
these reform efforts. The effects of reform on them would be profound. For example, there is evidence that to the peasants the restricted usefulness of the "official" religion in solving everyday problems with health, weather, and crops generated indifference to the practices of that religion by the early eighteenth century. ${ }^{81}$

The clerical and lay deputies to the Estates General of 1614, working within limits established by their perceptions of themselves and each other, were changing the lives and minds of the French far more than they realized. The Catholic Reformation was underway and France would never be the same.

${ }^{81}$ See Malcolm Greenshields, "What Happened in Quibou? The Catholic Reformation in the Village," Proceedings of the Annual Meeting of the Western Society for French History 18 (1991): 80-88; and J. Michael Hayden, "The Catholic Reformation at the Diocesan Level: The Example of Coutances in Normandy," ibid., 89-97. 